
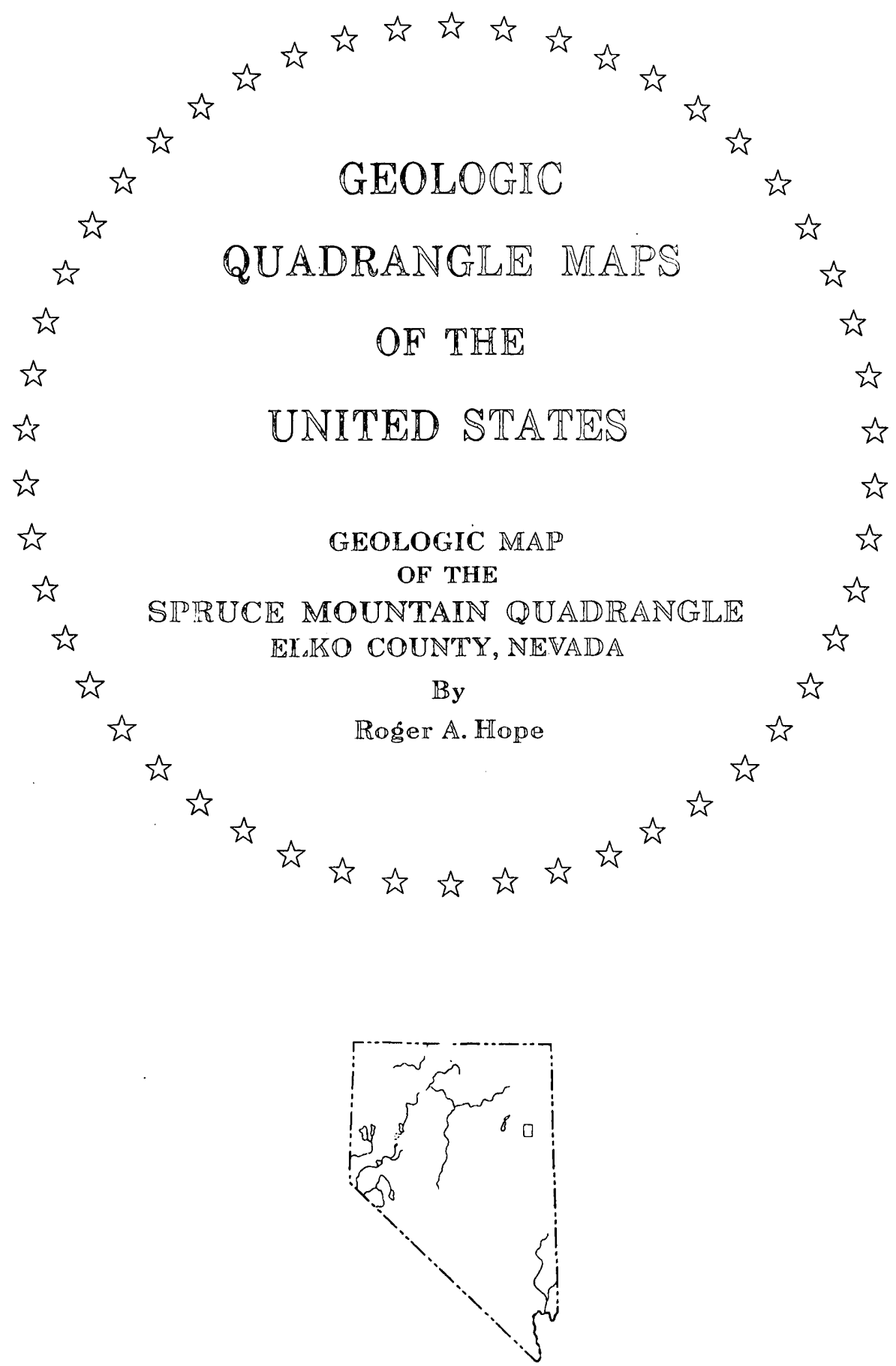

QUADRANGLE LOCATION 


\section{GEOLOGIC MAP OF THE SPRUCE MOUNTAIN \\ QUADRANGLE, ELKO COUNTY, NEVADA \\ By}

Roger A. Hope

\section{STRATIGRAPHY}

A brief description of each stratigraphic unit is given in the explanation. The units occur in other areas, where they have been extensively described. Peculiarities in the Spruce Mountain stratigraphy are described below.

Undifferentiated dolomite. - The 1,000-foot-thick interval above the Eureka Quartzite and below the Simonson Dolomite contains a heterogeneous assemblage of dolomite beds. To the east, in the Toana and Goshute Ranges, H. J. Bissell (written commun., 1966) was able to differentiate this interval into the Fish Haven Dolomite (Ordovician), Laketown Dolomite (Silurian), and Sevy Dolomite (here Devonian) with a combined thickness of 1,555 feet. The same interval in the central Pequop Range northeast of Spruce Mountain, assigned by Thorman (1962, p. 28-35) to the Ely Springs (Ordovician) and Laketown (Silurian) Dolomites, has a thickness of 1,685 feet.

Riepe Spring Limestone of Steele (1960). - The Riepe Spring Limestone was named by Steele $(1960$, p. 102) for exposures at the north end of Ward Mountain, White Pine County, where it is entirely of middle Wolfcamp (Late Pennsylvanian) age. In the Spruce Mountain quadrangle, rocks of similar lithology range from Missouri and Virgil (Late Pennsylvanian) to Wolfcamp (Early Permian) on the basis of fusulinids. Although the Riepe Spring is about 1,400 feet thick throughout the quadrangle, in three stratigraphic sections the thickness of the Upper Pennsylvanian part of the formation decreases to the south west from between 690 and 1,140 feet (section 1, fig. 1) to between 80 and 140 feet (section 2). The thickness of Lower Permian

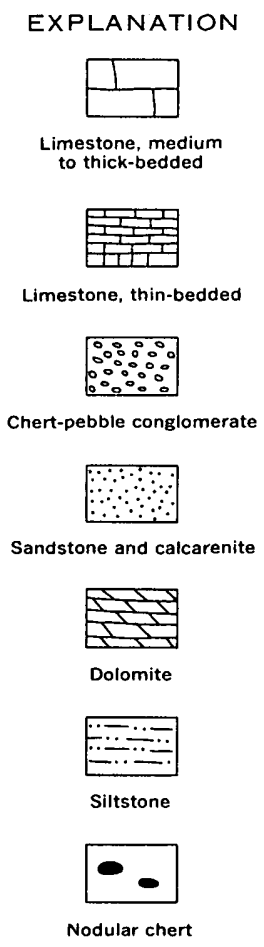

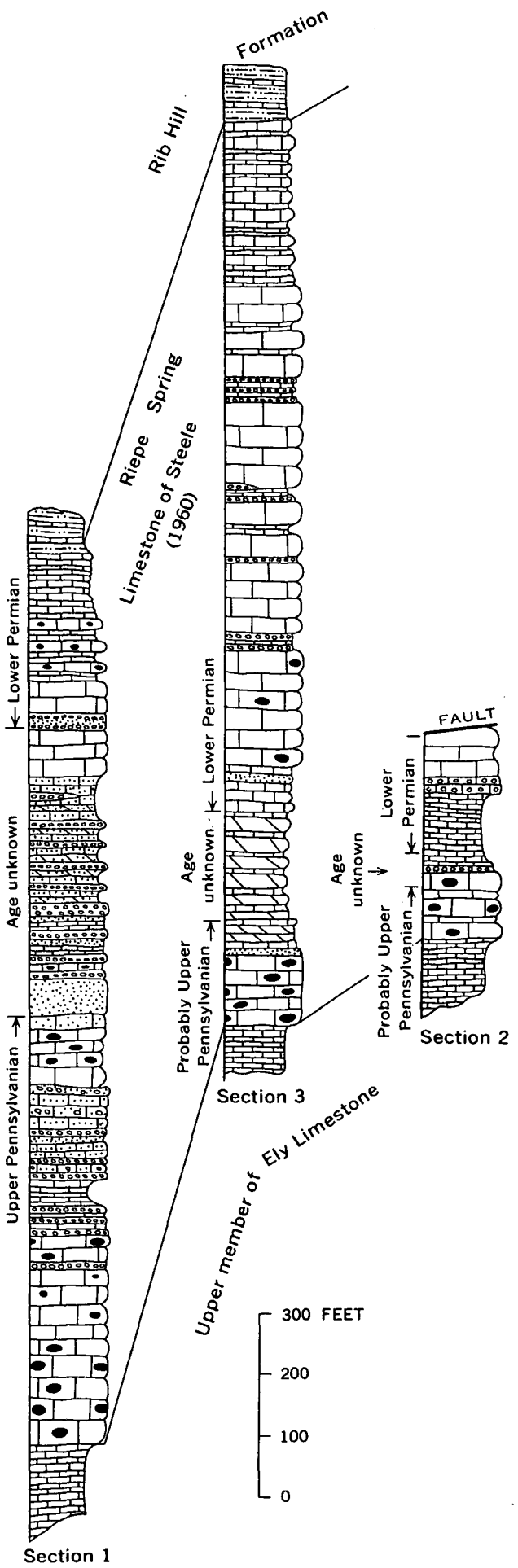

FIGURE 1. Three stratigraphic sections showing the relation between the Riepe Spring Limestone of Steele (1960) and the Pennsylvanian-Permian boundary. See map for location of sections. 
strata increases correspondingly. This indicates that the ElyRiepe Spring contact is time transgressive. Also significant is a marked decrease in the ratio of chert-pebble conglomerate to limestone between section 1 and sections 2 and 3 . A southward decrease in this ratio has also been noted in the southern $\mathrm{Pe}$ quop Range (G. Fraser, oral commun., 1968). At least half the conglomerate beds are of Late Pennsylvanian age at the north end of this quadrangle (section 1), and most, if not all, are of Early Permian age to the south (sections 2 and 3 ).

\section{STRUCTURE}

High-angle faults, trending most commonly north to northeast, break Spruce Mountain and Spruce Mountain Ridge into many separate blocks that have been differentially elevated and tilted. Most highly elevated, both structurally and topographically, is the horst bounded by two faults, here named the East and West faults. Only in this block and in the one just east of it are low-angle faults exposed.

Low-angle faults. - The three major low-angle faults are here named the North Peak, Spruce Spring, and South Peak faults. The North Peak fault dips about $15^{\circ} \mathrm{N}$. from the main (north) summit of Spruce Mountain and is exposed only between the East and West faults. A subsidiary low-angle fault in the upper plate joins the North Peak fault on the main summit but diverges up-structure to the east (see section $D_{-}-D^{\prime}$ ). In the next fault block to the east, the subsidiary fault is exposed and the North Peak fault is probably at a very shallow depth. Basal beds in the upper plate of North Peak fault are of the Chainman Shale and Diamond Peak Formation, except where the lower part of the Ely Limestone meets the fault. The Chainman, Diamond Peak, and lower part of the Ely to the east of the East fault must be in the upper plate, and it is most plausible that the North Peak fault underlies this whole area Similarly, west and north of the West fault, the Chainman Shale and Diamond Peak Formation must be in the upper plate and Spruce Mountain Ridge must be underlain by the North Peak fault.

The Spruce Spring and South Peak faults wrap around and dip about $15^{\circ}$ off the south end of Spruce Mountain. To the north, these faults are interpreted to steepen and to truncate the North Peak fault. The Spruce Spring fault lies structurally above and truncates the South Peak fault to the north and west (see sections $\mathrm{A}-\mathrm{A}^{\prime}$ and $\mathrm{F}-\mathrm{F}^{\prime}$ ). Strata in the upper and lower plates of both faults have nearly parallel eastward dips and are clearly truncated at the faults. A 200 -foot-thick zone of sheared and partially recrystallized Pogonip limestone under- lies the Spruce Spring fault, but this zone either pinches out or is not exposed where the Spruce Spring fault overrides the South Peak fault. Possibly, some of the curvature of these two faults was caused by upwarping during formation of the Spruce Mountain horst.

The direction of slip on these low-angle faults has not been determined, but for two reasons it is likely that the upper plates moved relatively westward. First, the strata in both upper and lower plates dip rather uniformly eastward (aside from some folding), and there is always a missing stratigraphic interval with younger rocks on older across the faults. If upper plate rocks slipped westward, net slip need not be large. Minimum magnitudes (assuming the slip was approximately perpendicular to the regional strike of bedding) would be 2-3 miles for the North Peak and Spruce Spring faults, and 1-2 miles for the South Peak fault. If upper plate rocks moved eastward, slip would have to be substantially greater. Second, large-scale folds overturned to the west and low-angle faults whose upper plates moved west are exposed east of this quadrangle in the southern Pequop Mountains (G. Fraser, written commun., 1968; Snelson, 1955). The entire southern part of the Pequop Mountains appears to be underlain by the North Peak fault.

High-angle faults. - The other faults in this range dip more steeply and have more northerly trends, although faults of all trends and curved traces are common, particularly east of the East fault. None of these faults is noticeably folded. Most show normal separations and indicate crustal elongation.

Some faults, exposed only in upper plate rocks, may have formed at the same time as the low-angle faults and may curve into them at depth. Faults in the upper plate of the Spruce Spring fault east of the East fault do not seem to cross the Spruce Spring fault (see sections $A-A^{\prime}$ and B-B'). Faults older than the low-angle faults have not been demonstrated.

The East and West faults, which bound the Spruce Mountain horst, as well as a parallel fault about a mile east of the East fault are clearly younger than both the low-angle faults and most of the other high-angle faults. This can be seen by their cross-cutting relationships, as well as their more pronounced topographic expression. South of the canyon containing the Black Forest mine, the East fault dips about $45^{\circ} \mathrm{E}$., but steepens to about $70^{\circ}$ farther north. Slip apparently increases southward (see sections $\mathrm{E}-\mathrm{E}^{\prime}, \mathrm{D}-\mathrm{D}^{\prime}$, and $\mathrm{C}-\mathrm{C}^{\prime}$ ). The reverse separation of the North Peak fault across the East fault in section E- $\mathrm{E}^{\prime}$ indicates either reverse or left-lateral slip. Either way it is likely that there has been rotation along the East fault. The West fault, which dips about $45^{\circ} \mathrm{W}$. and truncates the East fault to

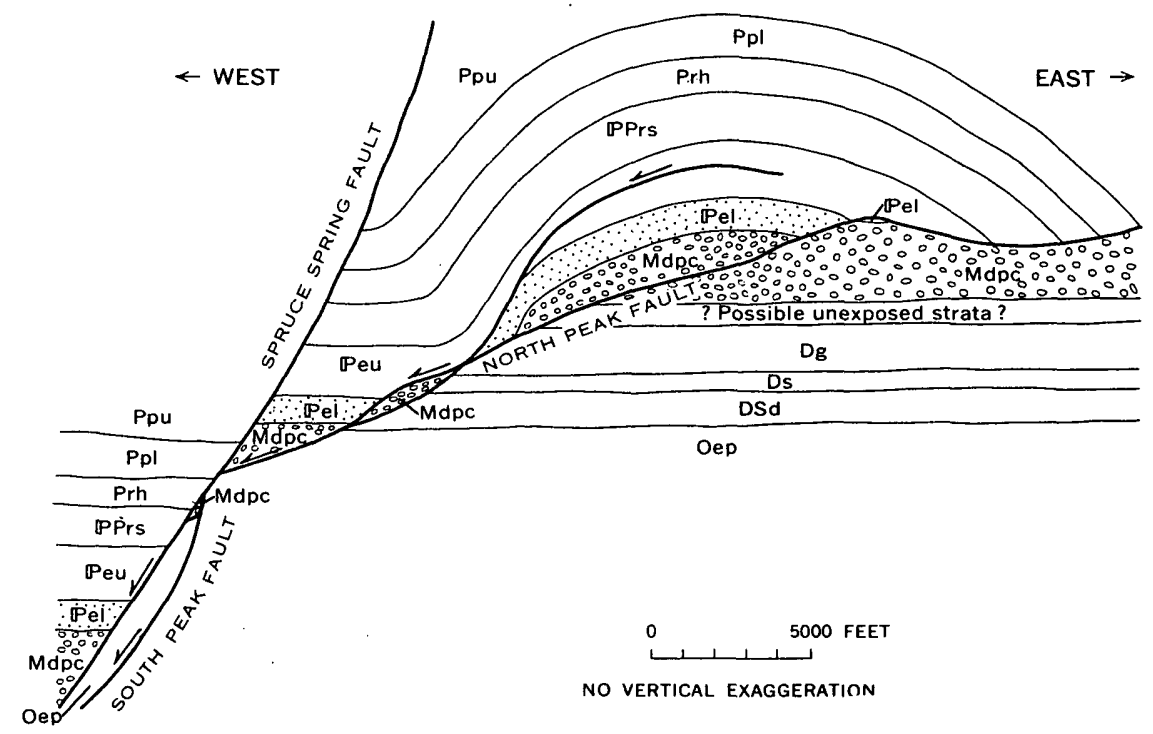

FIGURE 2. Hypothetical cross section of Spruce Mountain area after development of low-angle faults, but before high-angle faulting and eastward tilting. Lithologic symbols same as on map. 
the north, has a greater net slip than the East fault and probably formed as rocks of the range were tilted eastward.

If, as is postulated, the eastward tilting occurred simultaneously with the younger high-angle faulting; then the low-angle faults existed prior to tilting. Figure 2 shows what an eastwest cross section through Spruce Mountain would have looked like just prior to high-angle faulting and tilting. The low-angle faults would be south- to east-dipping normal faults. Folding in the upper plate of the North Peak fault could be attributed to a flattening of the dip as the fault followed the incompetent Chainman-Diamond Peak interval before cutting more steeply through the strata above and below.

Later Tertiary or Quaternary landslide. - The low bluff just east of U.S. Highway 93 is capped by a nearly flat resistant 50 -foot layer of limestone breccia overlying folded Tertiary tuffaceous sandstone, ash, and earthy limestone. The Tertiary strata are not deformed in contact with the breccia. Their folding appears to have preceded emplacement of the breccia. The breccia fragments are generally angular. Most clasts are 2-3 inches across, but blocks over a foot in diameter are fairly common. Many fragments have not moved far relative to one another, because details of their internal structure as well as their outlines can be matched. A band of limestone fragments containing rounded quartz sand grains can be traced along the face of the bluff near the base of the breccia. The band is undulatory, varies in thickness up to a maximum of about 3 feet, and contains admixed fragments of other lithologies-particularly toward the margins. About 99 percent of the breccia fragments probably represent the Guilmette Formation. Fossil fragments of spaghettilike Cladopora or Amphipora occur in a few clasts. The Guilmette fragments contain abundant calcite veins and are brecciated from an earlier cataclastic event. Other minor lithologies are fusulinid-bearing limestone (probably derived from the lower part of the Pequop Formation of Steele, $1959,1960)$ and quartzite.
Other outcrops of brecciated and veined Guilmette Formation occur only on the summit and surrounding parts of Spruce Mountain where brecciation is spatially and probably genetically related to the overlying North Peak fault. Therefore, the previously brecciated limestone mass near the highway apparently slid from Spruce Mountain. It was partly disaggregated during transport, because its areal outcrop is considerably larger than the source area and because there is a small admixture of exotic fragments. This mass, interpreted here as a landslide, has been previously called the upper plate of a thrust (Wheeler and McNair, 1950) and the basal part of a dissected and faulted alluvial fan (Hazzard and Moran, 1952, p. 845-848).

\section{REFERENCES}

Hazzard, J. C., and Moran, W. R., 1952, Reported late Tertiary thrusting in northeastern Nevada: Am. Assoc. Petroleum Geologists Bull., v. 36, no. 5, p. 844-856.

Snelson, Sigmund, 1955, Geology of the southern Pequop Mountains, Nevada: Univ. Washington, M.S. thesis.

Steele, Grant, 1959, Basin-and-range structure reflects Paleozoic tectonics and sedimentation [abs.]: Am. Assoc. Petroleum Geologists, v. 43 , no. 5 , p. 1105 .

1960, Pennsylvanian-Permian stratigraphy of east-central Nevada and adjacent Utah, in Boettcher, J. W., and Sloan, W. W., Jr., eds., Guidebook to the geology of east-central Nevada: Intermontane Assoc. Petroleum Geologists-Eastern Nevada Geol. Society, p. 91-113.

Thorman, C. H., 1962, Structure and stratigraphy of the Wood Hills and a portion of the northern Pequop Mountains, Elko County, Nevada: Ph.D. thesis, Univ. Washington, University Microfilms, Inc., Ann Arbor, Mich., 218 p.

Wheeler, H. E., and McNair, A. H., 1950, Late Tertiary thrusting in northeastern Nevada [abs.]: Geol. Soc. America Bull., v. 61 , no. 12 , pt. 2 , p. 1513. 